\title{
Nutritional therapy in the treatment of pressure injuries: a systematic review
}

Karina Díaz Leyva de Oliveira' Adriana Haack ${ }^{2}$ Renata Costa Fortes ${ }^{2}$

\section{Abstract}

Objective: to review literature on the use of nutritional therapy in the treatment of pressure injuries. Methods: a systematic review of the PubMed, Lilacs and Scielo databases was performed, with studies in the English and Portuguese languages published in the last five years selected. Result: three articles that investigated the use of different doses of arginine, a mixture of amino acids and nutritional supplements enriched with arginine, zinc and antioxidants were analyzed. The studies found that there was a reduction in the area of wounds in the intervention groups, although the difference in size was not significant in all the articles. Conclusion: nutritional intervention should be considered an integral part of the treatment of pressure injuries. The use of certain nutrients may positively affect the healing process of such injuries. Due to the heterogeneity of the methodologies used, the small sample size and the range of intervention times and nutrients used, more scientifically rigorous studies are recommended to create an evidence based nutritional intervention model for the treatment of pressure injuries.

\footnotetext{
Escola Superior de Ciências da Saúde, Fundação de Ensino e Pesquisa em Ciências da Saúde (FEPECS), Programa de Residência em Nutrição Clínica. Brasília, DF, Brasil.

2 Escola Superior de Ciências da Saúde, Secretaria de Estado de Saúde do Distrito Federal. Brasília, DF, Brasil.
}

Keywords: Pressure Ulcer. Wound Healing. Nutrition Therapy. Diet Therapy. 


\section{INTRODUCTION}

Pressure ulcers (PU) are described as localized damage to the underlying skin and/or tissue, usually over a bony prominence. They may be related to medical equipment or other types of devices and are considered a global problem. They can be caused by prolonged and/or intense pressure or shear forces ${ }^{1}$. In addition to worsening the quality of life of hospitalized patients, PU increase the length of hospital stays and the cost of treatment.

In recent years, the prevalence of pressure ulcers has increased due to the increased life expectancy of the population. One of the indicators of risk for the development of PU is the age factor, especially in patients aged 65 years or older. The non-healing of ulcers affects three to six million people from this age group, representing $85 \%$ of sufferers of such events ${ }^{3,4}$. The occurrence of PU has been observed in $36 \%$ of elderly patients with hip fractures and in 10 to $35 \%$ of individuals at the time of admission to long-term care facilities (LTCF) ${ }^{4}$. In Brazil, a study performed in a LTCF for the elderly in Fortaleza found a mean prevalence of pressure ulcers of $18.8 \%{ }^{5}$. In Ribeirão Preto in the state of São Paulo, a study of adults and elderly persons receiving home care identified a prevalence of $21.7 \%$. In a study of patients living in an area covered by the Family Health Strategy (FHS) in Teresina, Piaui, where the majority (79.4\%) of the sample were elderly, the prevalence of PU was $23.5 \%$.

Turning to the relationship between PU and nutrition, studies have indicated a low association between malnutrition and the development of PU and delayed healing. Low Body Mass Index values are associated with reduced body fat and, consequently, less protection against pressure in bony prominence areas ${ }^{8}$. A study of high risk and hospitalized individuals found that $29 \%$ of such patients were malnourished, and of these $17 \%$ developed PU over a four-week period, while only $9 \%$ of non-malnourished patients suffered such lesions in the same period ${ }^{3}$. A multi-center study conducted in several hospitals in Brazil from 2009 to 2011 indicated a prevalence of $16.9 \%$ of $\mathrm{PU}$, and found that $52.4 \%$ of patients were malnourished. Fifteen years earlier, the Inquérito Brasileiro de Avaliaçäo Nutricional Hospitalar (the Brazilian Hospital Nutritional Evaluation Enquiry) (IBANUTRI) found that malnutrition was present in $48 \%$ of hospitalized patients?

Nutritional therapy (NT) is recommended in cases of pressure ulcers where patients are unable to meet their nutritional needs by the conventional oral route $^{10}$. The nutritionist is responsible for creating a dietary prescription based on nutritional diagnosis guidelines ${ }^{11}$.

The healing process consumes energy, mainly through the use of carbohydrates in the form of glucose. In order for the body to avoid using proteins in this process, an adequate calorie supply is required. ${ }^{3}$. From 30 to $35 \mathrm{kcal} / \mathrm{kg} /$ day of energy and 1.2 to $1.5 \mathrm{~g} /$ $\mathrm{kg} /$ day of proteins are recommended, in addition to 1 $\mathrm{mL} / \mathrm{kcal}$ of fluid intake. In patients with more than one PU and/or very large lesions or major catabolic situations, as well as those who do not have other comorbidities, the supply of at least $1.5 \mathrm{~g} / \mathrm{kg} /$ day can be considered. The use of formulas with a higher protein content and immunomodulatory nutrients has been recommended in the treatment of patients with $\mathrm{PI}^{10}$.

Several supplements for enteral nutritional therapy (ENR) and oral, nasogastric, nasoenteral or percutaneous (gastrostomy) nutritional supplementation have been commercially developed to prevent and treat PU. These formulas are mainly composed of protein, zinc, vitamin $\mathrm{C}$, arginine and glutamine ${ }^{3}$.

The objective of the present study was to perform a literature review of the use of NT in the treatment of pressure ulcers.

\section{METHODS}

A systematic review of literature was conducted in August and September 2016 in accordance with the Preferred Reporting Items for Systematic Reviews and Meta-Analyses (PRISMA) methodology ${ }^{12}$. To develop the research question the PICO acronym was used ${ }^{13}: \mathrm{P}$ - population and problem (adults and elderly persons with PU); I - intervention (use of nutrition therapy); C - comparison (no special formula, or different formulas, or use of specific nutrients and immunonutrients, or differences in composition and/or dosage); $\mathrm{O}$ - outcomes (partial or total healing, stability of total area, reduction of 
exudate, reduction of devitalized tissues and others). The research question was: What NT was used to improve the healing of PU in adults and the elderly?

A search was carried out of bibliographic data on the PubMed, Lilacs and Scielo databases, selecting publications performed in the last five years in the English and Portuguese languages. The following descriptors from the Medical Subject Headings (MeSH) system were used: pressure ulcer, bed sores, bedsore, decubitus ulcer, pressure sore, wound healing, nutrition therapy, diet therapy together with the following from the Descritores em Ciências da Saúde (Health Science Descriptors) (DeCS): pressure ulcer, decubitus eschar, healing, nutritional therapy, diet therapy, combined with Boolean operators (AND and OR).

The inclusion criteria were: randomized clinical trial design, studies involving humans, subject age over 18 years, oral or enteral diet administration route, and pressure ulcers only. Publications such as literature reviews, dissertations, theses, editorials and clinical guidelines and studies of injuries of other etiologies were excluded.
The studies were initially selected from their titles and abstracts after consulting the databases. They were then read in full in order to apply the predefined inclusion and exclusion criteria. For the extraction of data from the articles, an instrument was prepared containing the following information: authors, year of publication, study location, sample size, intervention, duration, results and outcome evaluation.

\section{RESULTS}

Following searches in the databases using the previously mentioned descriptors, 117 articles were found, with 98 in PubMed, 16 in Lilacs and 3 in Scielo. Eighteen studies were selected for a complete reading. The most common reasons for exclusion at this stage were: type of wound with etiology other than PU (3), non-randomized studies (2) and systematic reviews (7), parenteral route of administration (2), and TN used for objectives other than the healing of PU (1). In the end, three articles were included in this systematic review (Figure 1).

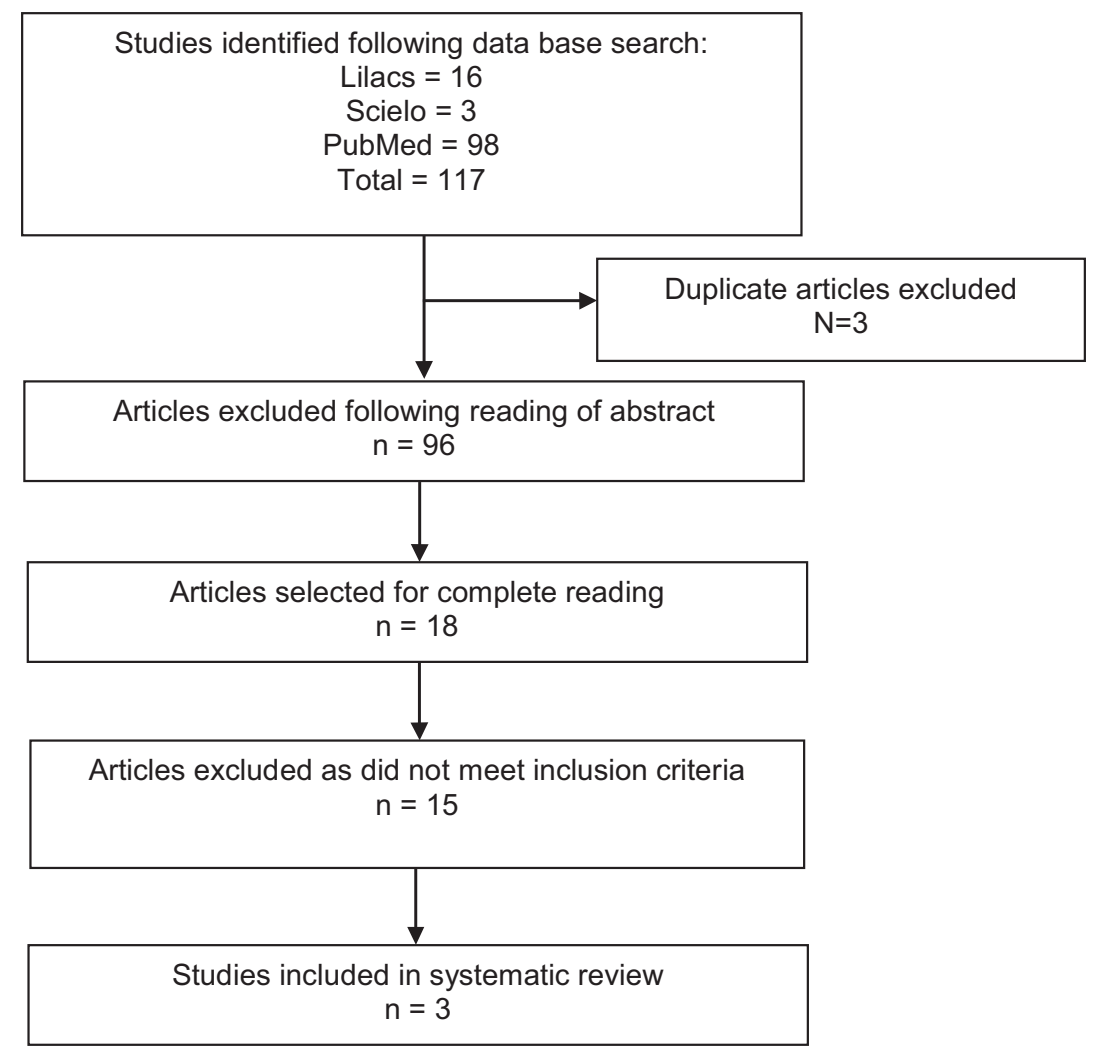

Figure 1. Flowchart of identification, selection and inclusion of studies. Distrito Federal, 2016. 
The nutrients studied were: arginine, a mino acid mixture [arginine, glutamine and beta-hydroxy-betamethylbutyrate (HMB)] and a formula enriched with zinc, arginine and antioxidants (Cubitan $\left.{ }^{\circledR}\right)$. The mean age varied from $67.5 \pm 4.9$ to $81.7 \pm 10.7$ years and 246 patients participated in the study, 86 (35\%) of whom were men and $160(65 \%)$ of whom were women. Of the studies analyzed, one was performed in Australia ${ }^{14}$, one in Singapore ${ }^{15}$ and one in Italy ${ }^{16}$. The study by Leigh et al. ${ }^{14}$ did not receive any type of funding, while the study by Wong et al. ${ }^{15}$ was supported by Abbot Laboratories Pte Ltd and the authors declared there were no conflicts of interest. Cereda et al..$^{16}$ received financing from the Azienda Ospedaliera Universitaria Maggiore della Carità and declared that the source of the financial support had no role in the project or the undertaking of the study. All the studies described how randomization was performed.

In terms of sample losses, Leigh et al. ${ }^{14}$ described reasons such as death and collateral effects. The losses in the study by Wong et al. ${ }^{15}$ included pneumonia related death and aversion to the supplement. Cereda et al. ${ }^{16}$ described death, hospitalization, transference and the resistance of the participants to the treatment as reasons for losses.

All the studies performed nutritional and anthropometric evaluations. Two of the works ${ }^{14,15}$ used the Subjective Global Assessment (SGA) and the Body Mass Index (BMI). Leigh et al. ${ }^{14}$ classified 52\% of the patients evaluated as malnourished. Wong et al. ${ }^{15}$ declared that $65 \%$ were malnourished or at risk of malnutrition. No significant alterations in weight were observed following the intervention in these two studies. The study by Cereda et al. ${ }^{16}$ evaluated only malnourished patients and used the BMI. The eight-week treatment resulted in an increase in body weight in both groups $(p<0.001)$.

Daily energy requirements were calculated in the study by Leigh et al. ${ }^{14}$ using the Schofield equation. Protein requirements were based on the recommended daily dose for subjects with PU, according to the National Pressure Ulcer Advisory Panel $(1.2-2 \mathrm{~g} / \mathrm{kg} \text { of body weight })^{17}$. Wong et al..$^{15}$ used from $30-35 \mathrm{kcal} / \mathrm{kg}$ of body weight and $1.2-2 \mathrm{~g} / \mathrm{kg}$ of body weight of protein, according to the stage of the pressure ulcer. Cereda et al. ${ }^{16}$ multiplied the result of the Harris-Benedict formula by a correction factor of 1.2 for physical activity and a PU stress factor of 1.1. Daily protein requirements were set at an intake of $1.5 \mathrm{~g} / \mathrm{kg}$ of body weight.

To evaluate the ulcer, one study ${ }^{16}$ used the Visitrak tool ${ }^{18}$ while the other two $^{14,15}$ employed the Pressure Ulcer Scale for Healing (PUSH) ${ }^{19}$. The primary outcome in the study by Leigh et al. ${ }^{14}$ was the healing rate of the PU. Wong et al. ${ }^{15}$ did not describe the outcome of the methodology, but also evaluated the healing of the ulcers using the PUSH tool. Cereda et al. ${ }^{16}$ describes a primary outcome of the reduction of the ulcer area at eight weeks, and secondary outcomes that included a reduction in area of $40 \%$ or more; full healing at eight weeks, and percentage change in area within four weeks.

Regarding the pressure ulcers themselves, Leigh et al. ${ }^{14}$ found that $74.2 \%$ were classified as grade II $(\mathrm{n}=23)$ and $32.3 \%$ were located in the sacral region $(\mathrm{n}=10)$. Of the 34 ulcers found by Wong et $a . .^{15}, 47.1 \%(n=16)$ were classified as grade IV and half were found in the sacral region. Cereda et al. ${ }^{16}$ obtained similar results: $40 \%$ of the PU were grade IV $(\mathrm{n}=80)$ and $64 \%$ were located in the sacral region ( $\mathrm{n}=128)$. Following the intervention, Leigh et al. ${ }^{14}$, who evaluated different doses of arginine, found a reduction in PUSH scores in the two groups $(p<0.001)$, although there were no significant differences in the healing rates between the groups ( $p=0.991$ ). Wong et al. ${ }^{15}$ used a mixture of amino acids and found similar results, but observed that the improvement in viable tissues was significantly higher in the experimental group $(p=0.02)$. Cereda et al. ${ }^{16}$ found that the use of a formula enriched with zinc, arginine and antioxidants resulted in a greater reduction in the area of the PU $(60.9 \%)$ than the standard formula $(45.2 \%)$.

One bias associated with the study by Leigh et al. ${ }^{14}$ was that it did not feature an active control group (for ethical reasons), and the authors questioned whether the healing rates would be different from the normal healing rates of PU. The sample size was small. In the study by Wong et al..$^{15}$ the determination of viable tissue was based on examination of the site and the 
retrospective analysis of photographs of sores, which may have led to bias in data interpretation. Both the time period and the survey size were small. When hospital discharge occurred, control of the use of the mixture (intervention) was via the verbal reports of the relatives. The study by Cereda et al. ${ }^{16}$ featured only malnourished patients.

Chart 1 shows the characteristics of the studies found.

Chart 1. Randomized clinical trials selected, describing authors, location, number of patients, intervention and results found. Distrito Federal, 2016.

\begin{tabular}{|c|c|c|c|c|c|}
\hline $\begin{array}{l}\text { Author/ } \\
\text { year of } \\
\text { publication }\end{array}$ & $\begin{array}{l}\text { Study } \\
\text { location }\end{array}$ & $\begin{array}{l}\text { Sample } \\
\text { (intervention/ } \\
\text { control) }\end{array}$ & Intervention & Duration & Results/evaluation of outcome \\
\hline $\begin{array}{l}\text { Leigh et al. } \\
2012\end{array}$ & $\begin{array}{l}\text { acute } \\
\text { care and } \\
\text { rehabilitation } \\
\text { hospital/ } \\
\text { Australia }\end{array}$ & $\begin{array}{l}23 \text { patients } \\
(12 / 11)\end{array}$ & $\begin{array}{l}\text { Standard hospital } \\
\text { diet (SHD) }+9 \mathrm{~g} \\
\text { de arginine - two } \\
\text { sachets vs } \\
\mathrm{SHD}+4.5 \mathrm{~g} \text { de } \\
\text { arginine - one sachet. } \\
\text { Each sachet } \\
\text { contained } 4.5 \mathrm{~g} \\
\text { of arginine, } 4 \mathrm{~g} \text { of } \\
\text { carbohydrate, } 155 \mathrm{mg} \\
\text { of vitamin C and } \\
40.5 \mathrm{mg} \text { of vitamin } \mathrm{E} .\end{array}$ & 3 weeks & $\begin{array}{l}\text { There was a reduction in the } \\
\text { initial PUSH scores of the two } \\
\text { groups }(8.9 \pm 0.7 \text { vs } 8.1 \pm 1.0 \\
\text { for } 4.5 \mathrm{~g} \text { and } 9.0 \mathrm{~g} \text { of arginine } \\
\text { groups, respectively, } p=0.507) \text {. } \\
\text { Although this reduction was } \\
\text { significant ( } p<0.001) \text { there was } \\
\text { no difference in the healing } \\
\text { rates of the two treatment } \\
\text { groups ( } p=0.991 \text { ). } \\
\text { There was no significant } \\
\text { difference in healing rates } \\
\text { based on arginine dosage } \\
\text { ( } p=0.393 \text { ). }\end{array}$ \\
\hline $\begin{array}{l}\text { Wong et al. } \\
2014\end{array}$ & $\begin{array}{l}\text { Acute care } \\
\text { hospital / } \\
\text { Singapore }\end{array}$ & $\begin{array}{l}23 \text { patients } \\
(11 / 12)\end{array}$ & $\begin{array}{l}\text { Recommended } \\
\text { diet for PU }+2 \\
\text { sachets of placebo } \\
\text { (carbohydrate, } \\
\text { calcium, flavoring) } \\
\text { vs Recommended } \\
\text { diet for PU }+2 \\
\text { sachets of a mixture } \\
\text { of amino acids [7g } \\
\text { of L-arginine, } 7 \mathrm{~g} \text { of } \\
\text { L-glutamine, } 7.9 \mathrm{~g} \text { of } \\
\text { carbohydrate, } 1.5 \mathrm{~g} \\
\text { of beta-hydroxy- } \\
\text { beta-methylbutyrate } \\
\text { (HMB), } 200 \mathrm{mg} \text { of } \\
\text { calcium and orange } \\
\text { flavoring]. }\end{array}$ & 2 weeks & $\begin{array}{l}\text { The PUSH scores were } \\
\text { significantly reduced in the } \\
\text { two groups: the experimental } \\
9.63 \pm 1.09 \text { (CI } 95 \%, 7.31 \text { to } \\
11.94, p<0.001) \text { and the placebo } \\
10.63 \pm 1.06 \text { (CI } 95 \%, 8.37 \text { to } \\
12.88, p=0.009 \text { ). However, } \\
\text { there was no overall difference } \\
\text { in the PUSH scores of the two } \\
\text { groups. } \\
\text { The improvement in the viable } \\
\text { tissue of the experimental } \\
\text { group was significantly greater } \\
\text { ( } p=0.02 \text { ), } 43.1 \% \text { (from } 42.8 \pm 6.6 \\
\text { to } 85.8 \pm 4.5 \text { ) compared to } \\
25.93 \% \text { (from } 57.2 \pm 7.4 \text { to } \\
83.1 \pm 5.0 \text { ) in the placebo group. }\end{array}$ \\
\hline
\end{tabular}


continued from Chart 1

\begin{tabular}{|c|c|c|c|c|c|}
\hline $\begin{array}{l}\text { Author/ } \\
\text { year of } \\
\text { publication }\end{array}$ & $\begin{array}{l}\text { Study } \\
\text { location }\end{array}$ & $\begin{array}{l}\text { Sample } \\
\text { (intervention/ } \\
\text { control) }\end{array}$ & Intervention & Duration & Results/evaluation of outcome \\
\hline $\begin{array}{l}\text { Cereda et al. } \\
2015\end{array}$ & $\begin{array}{l}\text { Long } \\
\text { term care } \\
\text { facilities and } \\
\text { home care } \\
\text { services / } \\
\text { Italy }\end{array}$ & $\begin{array}{l}200 \\
\text { malnourished } \\
\text { patients } \\
(101 / 99)\end{array}$ & $\begin{array}{l}\text { Standard oral diet } \\
\text { (SOD) }+400 \mathrm{ml} / \text { day } \\
\text { of oral nutritional } \\
\text { supplement (ONS) } \\
\text { vs SOD }+400 \mathrm{ml} / \\
\text { day of ONS with } \\
\text { similar values of } \\
\text { calories and proteins, } \\
\text { enriched with } \\
\text { zinc, arginine and } \\
\text { antioxidants (vitamin } \\
\text { C, E). }\end{array}$ & 8 weeks & 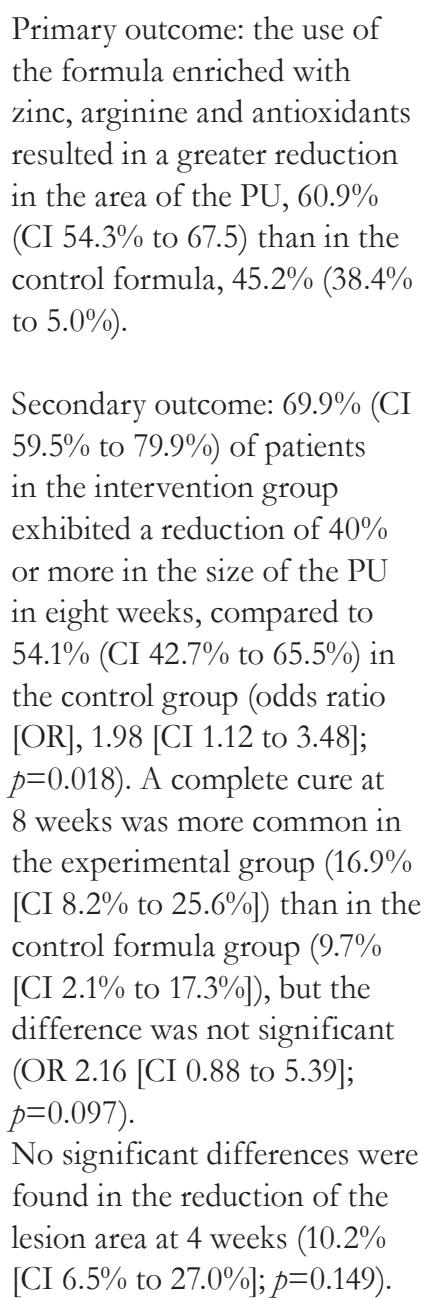 \\
\hline
\end{tabular}

\section{DISCUSSION}

The objectives of nutritional therapy in patients with pressure ulcers include the promotion of tissue regeneration and the facilitating of the healing process ${ }^{20}$. The main nutrients used in the studies were arginine, beta-hydroxy-beta-methylbutyrate, zinc and antioxidants. Other substances were also included in the supplements used, such as glutamine, selenium, copper and vitamin $C^{14-16}$.

Carbohydrates participate in phagocytic activity, cell proliferation and fibroblastic function, with recommended levels around $50 \%$ to $60 \%$ of the energy substrate. Proteins participate in neovascularization, fibroblast proliferation, collagen synthesis, and leukocyte production and migration ${ }^{20}$.

The main immunonutrients used in enteral formulations for the treatment of pressure lesions are arginine, glutamine and amino acids, which exercise a substrate function in the biochemical pathways responsible for mediating collagen synthesis and immune response. Arginine is a substrate for ornithine, nitric oxide and proline, which results in vasodilation, synthesis and collagen deposition, as well as being a conditionally essential amino acid, necessary during the active growth phases and in the healing process, diabetes and stress situations. Glutamine is the most abundant free amino acid in 
the body. Classified as a non-essential amino acid, its synthesis, in critical situations of metabolic stress, does not meet the demand required by the organism. Glutamine has been shown to be important in healing as it is related to collagen synthesis and the proliferation of inflammatory cells $\mathrm{s}^{3,21,22}$.

Beta-hydroxy-beta-methylbutyrate supplementation is associated with an increase in muscle mass and may inhibit muscle proteolysis and modulate protein turnover. A quantity of $3 \mathrm{~g} /$ day can increase the formation of collagen, stimulating wound healing ${ }^{15}$.

Zinc, copper and selenium also appear to be beneficial to the healing process. Zinc is a cofactor for the formation of collagen, granulation and epithelial tissue, has an antioxidant function and is important for protein synthesis. Copper participates in the cross-linking reactions of collagen, elastin and the elimination of free radicals ${ }^{3,23}$. Selenium is required for the functioning of the glutathione system, responsible for the management of inflammation induced by oxidative stress ${ }^{24}$. Vitamin $\mathrm{C}$ acts on the formation of collagen and the functioning of neutrophils and macrophages in the inflammatory phase. It also acts as a reducing agent, protecting copper and iron from oxidative damage, as well as participating in all the healing stages ${ }^{23,24}$.

The majority of participants in the studies were elderly, as illustrated by the advanced average age. Elevated age is considered a risk factor for the development of PU, probably due to changes in the skin and subcutaneous tissue of the elderly during the aging process, making it more fragile and susceptible to pressure, friction and shear forces. There was a predominance of females, characterizing what literature describes as "the feminization of old age", a phenomenon that also occurs in Brazil ${ }^{26}$.

A systematic review by Pedroni et al. ${ }^{27}$ evaluated the impact of malnutrition on the development and severity of PU and revealed, through eight studies, that the risk of developing pressure ulcers is higher in malnourished patients. Four studies showed that the severity of malnutrition increases the likelihood of having more severe PU or a greater number of lesions. Another study observed that pressure ulcers and their severity were directly associated with malnutrition, finding that $98 \%$ of those with
PU of severity greater than or equal to grade II were malnourished ${ }^{28}$. Nutritional status interferes directly with tissue repair. Malnutrition is related to inadequate wound healing, decreased fibroblast production, neoangiogenesis and collagen synthesis, as well as reduced tissue remodeling capacity ${ }^{10}$.

Leigh et al. ${ }^{14}$ observed that well-nourished patients displayed greater improvement in healing rates than malnourished patients, although the difference was not significant $(p=0.057)$. Wong et al. ${ }^{15}$ and Cereda et al. ${ }^{16}$ did not evaluate the relationship between healing rate and nutritional status.

A recent systematic review on the use of argininecontaining supplements found that such substances resulted in a significant improvement in PU healing in malnourished patients and those with normal nutritional status ${ }^{29}$. Another study observed that the PU of patients who received the arginine-enriched supplement were significantly smaller than those of the control group $(p<0.016)$. The PUSH score in the intervention group was significantly lower than control $(p<0.033)$ in the eighth week ${ }^{30}$. The study which evaluated different doses of arginine in this systematic review found a significant reduction in PU severity over time $(p<0.001)$, with no evidence of differences in healing rate between the two doses of arginine $(p=0.991)$. The authors suggest that a $4.5 \mathrm{~g}$ dose of arginine per day may promote a similar benefit in healing to a $9 \mathrm{~g}$ dose $\mathrm{e}^{14}$. Wong et al. ${ }^{15}$ concluded that the use of specialized amino acids does not appear to reduce wound size and PUSH scores, but may improve tissue viability after two weeks. In both studies the follow-up time was short, with three and two weeks respectively.

In a previous study performed by Cereda et al. ${ }^{31}$ which featured the application of a formula enriched with arginine, zinc and antioxidants for 12 weeks, the differences between the interventions were statistically significant in terms of the area of the PU in week $8(\mathrm{p}<0.05)$ and in the PUSH score at week $12(p<0.05)$. In a more recent study, NT effectively improved the healing of PU ( $\mathrm{p}<0.001)$ in both groups, with a larger area in the intervention group at the eighth week ${ }^{16}$.

This systematic review presented some limitations, as the sample sizes of the studies included were small, ranging from 23 to 200 subjects. The 
studies employed different outcomes, nutritional assessment, proportion of areas and tissue evaluation tools (Visitrak, PUSH), and follow-up times, ranging from two to twelve weeks.

\section{CONCLUSION}

The therapeutic benefits of nutrition should be encouraged by multi-professional teams. Nutritional intervention should be considered an integral part of the treatment of pressure ulcers. The evaluation of the nutritional status of patients is recommended, as is ensuring adequate energy and protein intake as recommended by current guidelines.

Several studies have pointed to the presence of certain nutrients that can positively affect the healing process of pressure ulcers. The evidence of supplementation with arginine and other amino acids is generally favorable, but is confused by the addition of other nutrients in available commercial preparations and by the fact that the study periods involved have been relatively short.

The use of nutritional supplements enriched with arginine, zinc and antioxidants effectively aided the healing of PU in malnourished patients, although they may have a different effect on patients with adequate nutritional status.

More scientifically rigorous studies with standardized interventions and more participants are needed to create an evidence-based nutritional intervention model for the treatment of PU.

\section{REFERENCES}

1. Edsberg LE, Black JM, Goldberg M, McNichol L, Moore L, Sieggreen M. Revised National Pressure Ulcer Advisory Panel Pressure Injury Staging System. J Wound Ostomy Continence Nurs. 2016;43(6):585-97.

2. Menegon DB, Bercini RR, Santos CT, Lucena AF, Pereira AGS, Scain SF. Análise das subescalas de Braden como indicativos de risco para úlcera por pressão. Texto \& Contexto Enferm. 2012;21(4):854-61.

3. Blanc G, Meier MJ, Stocco JGD, Roehrs H, Crozeta $\mathrm{K}$, Barbosa DA. Efetividade da terapia nutricional enteral no processo de cicatrização das úlceras por pressão: revisão sistemática. Rev Esc Enferm USP. 2015;49(1):152-61.

4. Moraes JT, Borges EL, Lisboa CR, Cordeiro DCO, Rosa EG, Rocha NA. Conceito e classificação de lesão por pressão: atualização do National Pressure Ulcer Advisory Panel. Rev Enferm Cent.-Oeste Min. 2016;6(2):2292-2306.

5. Freitas MC, Medeiros ABF, Guedes MVC, Almeida PC, Galiza FT, Nogueira JM. Úlcera por pressão em idosos institucionalizados: análise da prevalência e fatores de risco. Rev Gaúch Enferm. 2011;32(1):143-50.

6. Moro JV, Caliri MHL. Úlcera por pressão após a alta hospitalar e o cuidado em domicílio. Esc Anna Nery Rev Enferm. 2016;20(3):1-6.
7. Bezerra SMG, Luz MHBA, Andrade EMLR, Araújo TME, Teles JBM, Caliri MHL. Prevalência, fatores associados e classificação de úlcera por pressão em pacientes com imobilidade prolongada assistidos na Estratégia Saúde da Família. Rev Estima [Internet]. 2014 [acesso em 26 jul. 2016];12(2):1-8. Disponível em: http://www.revistaestima.com.br/index/php/ estima/article/view/95

8. Sancho A, Albiol R, Mach N. Relationship between nutritional status and the risk of having pressure ulcers in patients included in a home care program. Atencion Primaria. 2012;44(10):586-94.

9. Brito PA, Generoso SV, Correia MIT. Prevalence of pressure ulcers in hospitals in Brazil and association with nutritional status: a multicenter, cross-sectional study. Nutrition. 2013;29(4):646-9.

10. Sociedade Brasileira de Nutrição Parenteral e Enteral; Associação Brasileira de Nutrologia; Sociedade Brasileira de Clínica Médica. Projeto Diretrizes. Terapia Nutricional para Portadores de Úlceras por Pressão [Internet]. [Sem Local]: [Sem Publicador]; 2011 [acesso em 28 jul. 2016]. Disponível em: https:// diretrizes.amb.org.br/_BibliotecaAntiga/terapia_ nutricional_para_pacientes_portadores_de_ulceras_ por_pressao.pdf 
11. Brasil. Resolução CFN N³80/2005. Dispõe sobre a definição das áreas de atuação do nutricionista e suas atribuições, estabelece parâmetros numéricos de referência, por área de atuação, e dá outras providências [Internet]. [acesso em 28 jul. 2016]. Disponível em: http://www.cfn.org.br/novosite/pdf/ res/2005/res380.pdf

12. Moher D, Liberati A, Tetzlaff J, Altman DG; PRISMA Group. Preferred reporting items for systematic reviews and meta-analyses: the PRISMA statement. Ann Intern Med. 2009;151(4):26-9.

13. Higgins JPT, Green S, editors. Cochrane Handbook for Systematic Review of Interventions: version 5.1.0 [Internet]. [Sem Local]: Cochrane Collaboration; 2009 [acesso 25 jun. 2017]. Disponível em: http//:www. cochrane-handbook.org

14. Leigh B, Desneves K, Rafferty J, Pearce L, King S, Woodward MC, et al. The effect of different doses of an arginine-containing supplement on the healing of pressure ulcers. J Wound Care. 2012;21(3):150-6.

15. Wong A, Chew A, Wang CM. The use of a specialised amino acid mixture for pressure ulcers: a placebocontrolled trial. J Wound Care. 2014;23(5):259-69.

16. Cereda E, Klersy C, Serioli M, Crespi A, D’Andrea F. A Nutritional formula enriched with arginine, zinc and antioxidants for the healing of pressure ulcers. Ann Intern Med. 2015;162(3):167-74.

17. Dorner B, Posthauer ME, Thomas D; National Pressure Ulcer Advisory Panel. The role of nutrition in pressure ulcer prevention and treatment: National Pressure Ulcer Advisory Panel white paper. Adv Skin Wound Care. 2009;22: 212-21.

18. Eberhardta TD, Kessler M, Soares RSA, Lima SBS, Fonseca GGP, Rodrigues LR. Mensuração de feridas: revisão da literatura. Ciênc Saúde. 2015;8(2):79-84.

19. Espírito-Santo PF, Almeida SA, Silveira MM, Salomé GM, Ferreira LM. Uso da ferramenta Pressure Ulcer Scale for Healing para avaliar a cicatrização de úlcera crônica de perna. Rev Bras Cir Plást. 2013;28(1):133-41.

20. Dalapicola MM. A importância do suporte nutricional em pacientes portadores de úlcera de pressão. Cad Saúde Desenv. 2013;2(2):76-89.

21. Little MO. Nutrition and skin ulcers. Curr Opin Clin Nutr Metab Care. 2013;16(1):39-49.
22. Neyens JCL, Cereda E, Meijer EP, Lindholm C, Schols JMGA. Arginine-enriched oral nitritional supplementation in the treatment of pressur ulcer: a literature review. Wound Med. 2017;16:46-51.

23. Posthauer ME, Banks M, Dorner B, Schols JMGA. The Role of Nutrition for Pressure Ulcer Management: National Pressure Ulcer Advisory Panel, European Pressure Ulcer Advisory Panel, and Pan Pacific Pressure Injury Alliance White Paper. Adv Skin Wound Care. 2015;28(4):175-88.

24. Aguiar AO, Oliveira BBR, Carnib LPA. Efeito dos antioxidantes vitamina $\mathrm{C}$ e selênio em pacientes queimados: uma revisão bibliográfica. Rev Bras Queimaduras. 2014;13(2):62-6.

25. Rogenski NMB, Kurcgant P. Avaliação da concordância na aplicação da Escala de Braden interobservadores. Acta Paul Enferm. 2012;25(1):24-8.

26. Santos AA, Mansano-Schlosser TCS, Ceolim MF, Pavarini SCI. Sleep, fragility and cognition: a multicenter study with Brazilian elderly. Rev Bras Enferm. 2013;66(3):351-7.

27. Pedroni L, Bonatto S, Mendes K. O impacto da desnutrição no desenvolvimento e na gravidade das úlceras por pressão: uma revisão da literatura. Rev Bras Ciênc Envelhec Hum. 2014;11(1):89-102.

28. Brito PA, Generoso SV, Correia MITD. Prevalence of pressure ulcers in hospitals in Brazil and association with nutritional status: a multicenter, cross-sectional study. Nutrition. 2013;29(4):646-9.

29. Liu P, Shen WQ, Chen HL. Efficacy of arginineenriched enteral formulas for the healing of pressure ulcers: a systematic review. J Wound Care. 2017;26(6):319-23.

30. Van Anholt RD, Sobotka L, Meijer EP, Heyman H, Groen HW, Topinková E, et al. Specific nutritional support accelerates pressure ulcer healing and reduces wound care intensity in non-malnourished patientens. Nutrition. 2010;26(9):867-72.

31. Cereda E, Gini A, Pedrolli C, Vanotti A. Disease Specific, Versus Standard, Nutritional Support for the Treatment of Pressure Ulcers in Institutionalized Older Adults: a randomized controlled trial. Am Geriatr Soc. 2009;57(8):1395-402. 


\section{ERRATUM}

In the review article "Nutritional therapy in the treatment of pressure injuries: a systematic review", published in the Revista Brasileira de Geriatria e Gerontologia v. 20, n. 4, p. 562-570, 2017, DOI: http:// dx.doi.org/10.1590/1981-22562017020.160195, the names of two of the authors in reference 18 on P. 570 are incorrect.

Instead of Eberhardta, TD, Kesslera, M the reference should read Eberhardt, TD, Kessler, M. 